Revista Eletrônica de Direito Processual - REDP.

Rio de Janeiro. Ano 11. Volume 18. Número 1. Janeiro a Abril de 2017

Periódico Quadrimestral da Pós-Graduação Stricto Sensu em Direito Processual da UERJ

Patrono: José Carlos Barbosa Moreira. ISSN 1982-7636. pp. 209-235

www.redp.uerj.br

\title{
LA UTILIDAD DE LOS ODR EN LOS CASOS DE VIOLENCIA DE GÉNERO ${ }^{1}$
}

\section{THE UTILITY OF THE ODR TO THE SOLUTION OF GENDER VIOLENCE CASES}

Emiliano Carretero Morales

Profesor de Derecho Procesal y Resolución Alternativa de Conflictos Universidad Carlos III de Madrid, España. ecarrete@der-pu.uc3m.es

RESUMO: O presente artigo tem por objetivo analisar criticamente os chamados ODR (Online Dispute Resolutions) na resolução de casos de violência de gênero. Pretende-se discutir a legalidade e a legitimidade desse modelo em um contexto no qual medidas tradicionais do direito penal não têm surtido efeito no combate à violência de gênero. Por meio de uma análise crítica da doutrina é possível analisar se os ODR são um meio mais adequado do que o endurecimento de penas através alterações legislativas. Atenta-se também para o papel dos ODR no âmbito da justiça restaurativa em um contexto no qual se busca superar o caráter retributivo do direito penal.

PALAVRAS-CHAVE: Direito Penal - Justiça Restaurativa - Violência de Gênero - Resolução de Conflitos

ABSTRACT: This article aims to analyze how ODR (Online Dispute Resolution) may resolve cases of gender violence. It discusses the legality and legitimacy of this model in a context in which traditional measures of criminal law have not had an effect in the fight against gender violence. Through a critical analysis of the doctrine it's possible to analyze whether ODR is a more appropriate mean than incarcerate measures. It also focuses on the role of ODR in restorative justice in a context that seeks to overcome the retributive nature of criminal law.

KEYWORDS: Criminal Law - Restorative Justice - Gender Violence - Conflict Resolution

SUMARIO: 1 . INTRODUCCIÓN 2. ¿PUEDE RESULTAR ADECUADA LA JUSTICIA RESTAURATIVA EN LOS CASOS DE VIOLENCIA DE GÉNERO? 3. LA UTILIDAD DE LOS ODR EN LOS CASOS DE VIOLENCIA DE GÉNERO 3.1. Ventajas que pueden ofrecer los ODR

\footnotetext{
${ }^{1}$ Artigo recebido em 31/03/2017 sob dispensa de revisão.
} 
Revista Eletrônica de Direito Processual - REDP.

Rio de Janeiro. Ano 11. Volume 18. Número 1. Janeiro a Abril de 2017

Periódico Quadrimestral da Pós-Graduação Stricto Sensu em Direito Processual da UERJ

Patrono: José Carlos Barbosa Moreira. ISSN 1982-7636. pp. 209-235

www.redp.uerj.br

en el ámbito de la justicia restaurativa y, en concreto, en los casos de violencia de género 4.2. El papel del neutral en los ODR 4. CONCLUSIONES 5. BIBLIOGRAFÍA

\section{INTRODUCCIÓN}

Desde el día 1 de enero de 2003, fecha en la que comenzaron a computarse datos oficiales, hasta el final del año 2016, casi 900 mujeres han sido asesinadas en España, víctimas de la violencia de género

Año tras año y desde todos los sectores de nuestra sociedad se vienen reclamando medidas efectivas a fin de poner freno a la imparable lacra de la violencia de género, pero hasta la fecha la adopción de las sucesivas reformas legales y la propia Ley Orgánica 1/2004, de 28 de diciembre, de Medidas de Protección Integral contra la Violencia de Género se han mostrado claramente insuficientes.

Las reformas introducidas por la citada Ley focalizaron la atención en la adopción de medidas de protección a las víctimas de violencia de género y en el endurecimiento de las sanciones a los infractores a fin de intentar erradicar este tipo de comportamientos, sin embargo, en la práctica, las medidas de protección a las víctimas no han surtido los efectos esperados y la progresiva criminalización y judicialización del problema no ha supuesto la ansiada reducción del número de casos.

Tal y como señala PÉREZ GINÉS, “podemos constatar que con el endurecimiento de las penas no se ha logrado contener la alta tasa de criminalidad, ni se ha logrado reafirmar algún sentimiento de mayor seguridad por parte del ciudadano, sólo se ha conseguido el resquebrajamiento de los pilares de la confianza ciudadana en la justicia, y pasado al olvido la búsqueda de posibles alternativas a la aplicación. Además de que se ha producido una extrema politización de la política penal, la impaciencia de la sociedad ante el delito ha aumentado, como también la disposición de los políticos a aumentar la penalización como prueba de la predisposición a combatirlo ${ }^{2}$.

En el mismo sentido, OUBIÑA BARBOLLA apunta refiriéndose a los datos estadísticos en esta materia que "pueden hacerse una y mil lecturas, pero indudablemente una de las primeras es que el endurecimiento de las penas a los maltratadores y otras medidas previstas en la Ley Orgánica de Medidas de Protección Integral contra la Violencia de Género no han tenido un efecto disuasorio. Al

\footnotetext{
${ }^{2}$ PÉREZ GINÉS, C.A., «La mediación penal en el ámbito de la violencia de género (o las órdenes de protección de difícil control y cumplimiento)», en La Ley Penal, número 71, año VII, mayo 2010, p. 66.
} 
Revista Eletrônica de Direito Processual - REDP.

Rio de Janeiro. Ano 11. Volume 18. Número 1. Janeiro a Abril de 2017

Periódico Quadrimestral da Pós-Graduação Stricto Sensu em Direito Processual da UERJ

Patrono: José Carlos Barbosa Moreira. ISSN 1982-7636. pp. 209-235

www.redp.uerj.br

menos visiblemente, de hecho, podría hasta incluso haber ocurrido a la inversa"3.

Lamentablemente, las medidas penales adoptadas hasta el momento no han demostrado ser lo suficientemente disuasorias y, en ocasiones, producen en el agresor el efecto contrario al pretendido, generando en el mismo un sentimiento de mayor animadversión y venganza hacia la víctima y hacia el propio sistema. Las meras medidas preventivas o represivas no son suficientes para poner fin a los episodios de violencia que sufren las mujeres, siendo tristemente frecuentes los supuestos en que, a pesar de la adopción de dichas medidas, el infractor consigue eludirlas y repetir actos violentos contra su víctima que, en demasiadas ocasiones, acaban con fatales resultados.

Una de las cuestiones más controvertidas de la Ley 1/2004 ha sido la prohibición absoluta de utilizar la mediación en temas de violencia de género, contenida en el art. 44.5 de la misma. No se entienden muy bien las razones que llevaron al legislador a realizar esta previsión, máxime cuando la mediación no se encontraba siquiera regulada en el ámbito del proceso penal de adultos, ni existían datos de algún proyecto piloto realizado que desaconsejasen su utilización.

Los procedimientos judiciales no ofrecen en todo caso soluciones completas y adecuadas, es evidente que no siempre se consigue la pretendida pacificación del conflicto como realización del Derecho, es más, en determinadas ocasiones, las resoluciones judiciales lo que hacen es cronificar o enquistar aún más el problema subyacente que ha dado lugar al proceso y originar nuevas situaciones conflictivas que, a su vez, acaban judicializándose.

Hay conflictos que, por su especial naturaleza, o por las circunstancias concurrentes en los mismos, precisan de otro tipo de intervenciones de carácter multidisciplinar que ofrecen una mejor solución, por lo que se hace precisa la implementación de nuevos mecanismos de solución de conflictos que vengan a complementar a los ya conocidos y que garanticen a los ciudadanos un mejor acceso a la Justicia y al Derecho que demanda la nueva sociedad ${ }^{4}$. Tal y como señalan LOBO GUERRA y SAMPER LIZARDI, "resulta paradójico que precisamente en aquellos contextos donde es necesaria una intervención más completa, como es el caso de las familias con problemática de violencia, se limiten los recursos a utilizar"5.

\footnotetext{
${ }^{3}$ OUBIÑA BARBOLLA, S. "La distancia que les separa, la distancia que nos separa: mediación en casos de violencia doméstica en España y en otros sistemas", en GARCIANDÍA GONZÁLEZ, P.M. y SOLETO MUÑOZ, H. (Dirs.) Sobre la Mediación Penal (Posibilidades y Límites en un Entorno de Reforma del Proceso Penal Español), Thomson Reuters Aranzadi, Navarra, 2012, pág. 184.

${ }^{4}$ En este sentido, véase SOLETO MUÑOZ, H., «La Mediación en la Unión Europea», en Mediación y solución de conflictos. Habilidades para una necesidad emergente, SOLETO MUÑOZ, H. y OTERO PARGA, M. (Coord.), Tecnos, Madrid, 2007, p. 186.

${ }^{5}$ LOBO GUERRA, M. y SAMPER LIZARDI, F. “¿Es posible la mediación en aquellos casos en los que ha existido violencia de género?”, en GARCIANDÍA GONZÁLEZ, P.M. y SOLETO MUÑOZ, H. (Dirs.) Sobre la Mediación Penal..., op. cit., pág. 164.
} 
Revista Eletrônica de Direito Processual - REDP.

Rio de Janeiro. Ano 11. Volume 18. Número 1. Janeiro a Abril de 2017

Periódico Quadrimestral da Pós-Graduação Stricto Sensu em Direito Processual da UERJ

Patrono: José Carlos Barbosa Moreira. ISSN 1982-7636. pp. 209-235

www.redp.uerj.br

No se pretende caer en el presente trabajo en el simplismo de asegurar que la mediación es posible y positiva para todos los supuestos, y mucho menos aún para todos los casos de violencia de género, pero sí abrir una reflexión sobre la posibilidad de plantear su adecuación cuando concurran los presupuestos que hagan viable, e incluso aconsejable, su utilización.

En los asuntos de violencia de género, por su especial y compleja idiosincrasia, donde concurre un importante factor previo, cual es la relación víctima-agresor, la intervención judicial, normalmente, no surte los efectos deseados.

No hay que olvidar, como señala OUBIÑA BARBOLLA, que "la violencia de género encierra un conflicto jurídico y humano complejo en la medida en que se produce un hecho delictivo que lesiona un bien jurídico que todos hemos entendido digno de protección y que por eso se tipifica en el Código Penal. Sin embargo, la violencia de género también incluye un conflicto personal entre dos personas que mantienen o han mantenido una relación afectiva de mayor o menor duración; es más en muchas ocasiones esa relación continúa a pesar de la violencia"6.

Es una obviedad que las aristas del conflicto exceden con mucho las cuestiones meramente jurídicas, sin embargo en el proceso judicial sólo se van a tratar las cuestiones de carácter legal, pero no se va a hacer un abordaje de la relación interpersonal ${ }^{7}$.

El tratamiento de las cuestiones de violencia de género en el proceso judicial se centra en los hechos enjuiciados, olvidando que las personas involucradas en este tipo de violencia padecen un daño moral, familiar y personal difícil de dimensionar en términos estrictamente jurídicos, por lo que se hace precisa la necesidad de afrontarlo desde una perspectiva multidisciplinar que pueda ofrecer una solución de conjunto y ahí es donde los instrumentos de justicia restaurativa, como por ejemplo la mediación, aparecen como el complemento que puede aportar dicha solución ${ }^{8}$.

\footnotetext{
${ }^{6}$ OUBIÑA BARBOLLA, S. "La distancia que les separa, la distancia que nos separa: mediación en casos de violencia doméstica en España y en otros sistemas”, en GARCIANDÍA GONZÁLEZ, P.M. y SOLETO MUÑOZ, H. (Dirs.) Sobre la Mediación Penal..., op. cit., pp. 184-185.

7 Tal y como señalan RÍOS MARTÍN ET AL, “el desencuentro violento no se canaliza positivamente con medidas cautelares de alejamiento, o de carácter civil, o con la condena a la pena de prisión. Estas medidas legales tienen, sin duda, un efecto preventivo y de reproche, son necesarias, pero lo que subyace en los conflictos violentos en el ámbito doméstico es un deterioro relacional, cuya posible solución apunta justamente a un proceso que tienda a restablecer la comunicación para que se adopten las medidas civiles oportunas". RÍOS MARTÍN, J., PASCUAL RODRÍGUEZ, E., BIBIANO GUILLÉN, A., SEGOVIA BERNABÉ, J.L., La mediación penal y penitenciaria. Experiencias de diálogo en el sistema penal para la reducción de la violencia y el sufrimiento humano, Colex, Madrid, 2008, p. 107.

Por su parte, ZAFRA ESPINOSA DE LOS MONTEROS apunta que "para que la mediación penal cumpla su finalidad práctica en las partes y en la sociedad, es necesario que ésta se realice desde el trabajo conjunto de varias disciplinas. Es decir, cuando se comete un ilícito penal es indudable que el tema jurídico es importante, pero no es el único". ZAFRA ESPINOSA DE LOS MONTEROS, R., "La mediación penal: una alternativa a la resocialización", en GARCIANDÍA GONZÁLEZ, P.M. y SOLETO MUÑOZ, H. (Dirs.) Sobre la Mediación Penal..., op. cit., p. 114.

${ }^{8}$ En algunos países, se han venido utilizando programas de mediación como método de gestión de conflictos en asuntos de violencia de género, eso sí, no en todos los casos y siempre adoptando una serie de medidas excepcionales que
} 
Revista Eletrônica de Direito Processual - REDP.

Rio de Janeiro. Ano 11. Volume 18. Número 1. Janeiro a Abril de 2017

Periódico Quadrimestral da Pós-Graduação Stricto Sensu em Direito Processual da UERJ

Patrono: José Carlos Barbosa Moreira. ISSN 1982-7636. pp. 209-235

www.redp.uerj.br

Sin embargo, en nuestro país, desde diversos sectores se apunta que los beneficios de la justicia restaurativa y, en concreto, de la mediación no se pueden predicar respecto de los casos de violencia de género, porque se entiende que existe la amenaza constante de un riesgo para la salud física y psicológica de la propia víctima que se podría ver agravado de someter a ésta a un proceso de mediación en el que haya de encontrarse con su agresor. ${ }^{9}$.

Se pone, pues, el acento en el posible riesgo que existiría para la víctima en el caso de un encuentro o de una confrontación directa con su agresor, por lo que se desaconseja tajantemente la utilización de la mediación, sin embargo en lo que no se ha reparado es que en la mediación no existe la necesidad de enfrentar directamente a víctima y agresor, sino que se puede trabajar por separado con ambas partes y, además, cabe la posibilidad de utilizar mecanismos y herramientas que sirvan precisamente para paliar dichos riesgos, haciendo que las partes puedan comunicarse directamente sin tener que coincidir necesariamente en un mismo espacio físico.

En este sentido, los llamados ODR (Online Dispute Resolution) podrían ayudar a superar dichas suspicacias y a paliar algunas de las principales críticas que se vienen realizando a la referida posibilidad de introducir elementos de justicia restaurativa en asuntos de violencia de género, cuales

garanticen la protección y seguridad de la víctima. En otros, se han desarrollado programas, no ya de mediación propiamente dichos, sino de facilitación o de intervención familiar, orientados a complementar y mejorar la posible solución a los conflictos de violencia doméstica y de género. En definitiva, existe la sensación general de que la vía judicial no es suficiente para abordar adecuadamente la complejidad de este tipo de conflictos, de que se precisan otro tipo de actuaciones o mecanismos que vengan a complementar dicha vía. Véase en este sentido, OUBIÑA BARBOLLA, S. "La distancia que les separa, la distancia que nos separa: mediación en casos de violencia doméstica en España y en otros sistemas”, en GARCIANDÍA GONZÁLEZ, P.M. y SOLETO MUÑOZ, H. (Dirs.) Sobre la Mediación Penal..., op. cit., pp. 200-201.

En nuestro país se han realizado experiencias de mediación en casos de violencia de género cuando el expediente judicial ha sido archivado por cualquier caso. Tal y como ponen de manifiesto VALL RIUS y GUILLAMAT RUBIO, "la aplicación de la mediación en estos casos de denuncia de violencia de género, una vez han sido archivados por la autoridad judicial, ha demostrado ser un recurso de gran utilidad, ya que posibilita una respuesta positiva a las partes, evitando la sensación de vacío y de frustración que supone para la mujer el archivo de una demanda de justicia que para ella era necesaria e importante, y a la vez abre un canal de comunicación con la persona inicialmente acusada, ofreciéndole la oportunidad de colaborar conjuntamente en la búsqueda común de soluciones consensuadas al conflicto subyacente que generó el episodio o la situación denunciada. La opción de la mediación supone un recurso que les permitirá trabajar el conflicto de fondo que persiste desde otra óptica no conflictualizadora, sino constructiva, y la posibilidad de encontrar la respuesta más adecuada a su realidad que, en ocasiones, no es más que la necesidad de plantear y formalizar su ruptura, transitando hacia una separación o divorcio que la mediación puede facilitar y ayudar a encauzar de forma pacífica y consensuada". VALL RIUS, A. y GUILLAMAT RUBIO, A., "Mediación y violencia de género, una respuesta útil en los casos de archivo de la causa penal", Revista de Mediación, año 4, n 7, mayo 2011, p. 22.

${ }^{9}$ Precisamente, uno de los mayores recelos que suscita el uso de la mediación en los asuntos de violencia de género es, tal y como pone de manifiesto ESQUINAS VALVERDE, “que la mediación, en caso de ser efectuada en sustitución de las acostumbradas medidas penales y cautelares, incrementaría el peligro concreto para la víctima en cuanto a nuevas acciones violentas por parte de su perseguidor, ya que los mismos encuentros de conciliación y procesos de acercamiento entre las partes, lógicamente, no constituyen protección alguna contra las agresiones. Más aún, según se indica, la confrontación del autor durante las sesiones con sus actos pasados podría aumentar su nivel de agresividad y, de ese modo, incluso, exponer a la afectada a un riesgo mayor que el que habría existido en caso de no interponerse tal procedimiento de mediación". ESQUINAS VALVERDE, P., Mediación entre víctima y agresor en la violencia de género, Tirant lo Blanch, Valencia, 2008, p. 58. 
Revista Eletrônica de Direito Processual - REDP.

Rio de Janeiro. Ano 11. Volume 18. Número 1. Janeiro a Abril de 2017

Periódico Quadrimestral da Pós-Graduação Stricto Sensu em Direito Processual da UERJ

Patrono: José Carlos Barbosa Moreira. ISSN 1982-7636. pp. 209-235

www.redp.uerj.br

son la protección de la seguridad de la víctima o la posible manipulación del proceso por parte del agresor.

\section{2. ¿PUEDE RESULTAR ADECUADA LA JUSTICIA RESTAURATIVA EN LOS} CASOS DE VIOLENCIA DE GÉNERO?

Es la primera pregunta que habría que hacerse y desde mi punto de vista entiendo que sí, si bien no se puede generalizar porque obviamente tal aseveración no es válida para todos los casos de violencia de género y en aquellos donde efectivamente pueda serlo habrán de adoptarse las debidas cautelas y todas las medidas necesarias para la adecuada protección de la víctima.

Tradicionalmente, el Derecho penal se ha caracterizado por su carácter retributivo ${ }^{10}$, primando el castigo al infractor sobre la satisfacción de los intereses y necesidades de las víctimas.

Con relación a éstas últimas se han dejado de lado cuestiones importantes como la reparación o resarcimiento del daño, la recuperación del sentimiento de seguridad perdido tras la comisión del delito, o la llamada "victimización secundaria" derivada de su paso por el proceso judicial al que han de hacer frente ${ }^{11}$.

Tal y como señala SOLETO MUÑOZ, “en la mayoría de los sistemas penales, la víctima tiene derecho a una reparación económica, y muchas veces se permite su participación en el proceso, sin embargo dista mucho de tener el protagonismo que emocionalmente precisaría" ${ }^{12}$. Por lo que respecta a la reparación o resarcimiento del daño, en la práctica, las víctimas, normalmente, están más interesadas en expresar su situación, sus sentimientos, su deseos y, en definitiva, en la solución definitiva del conflicto planteado, que en el mero castigo al infractor o en una simple reparación económica. Sin embargo el sistema legal diseñado centra su atención precisamente en la sanción, en la represión, obviando que dicha respuesta no colma las necesidades de la víctima y, en pocas

\footnotetext{
${ }^{10}$ Como señala PERULERO GARCÍA, "la configuración actual del Derecho penal es de corte marcadamente retributive y su objetivo principal es la repression o castigo del delincuentes, lo que ha fomentado un progresivo incremento punitivo, tanto en la ampliación de conductas perseguibles como en la gravedad de las penas a imponer". PERULERO GARCÍA, D., "Hacia un modelo de justicia restaurativa: la mediación penal", en GARCIANDÍA GONZÁLEZ, P.M. y SOLETO MUÑOZ, H. (Dirs.) Sobre la Mediación Penal..., op. cit., p. 70.

${ }^{11}$ Tal y como ponen de manifiesto CASTILLEJO MANZANARES ET AL, "en el sistema judicial español, la victimización secundaria surge por el modo en que la víctima participa en el seno del proceso. En todo momento desconoce su papel en el curso de los acontecimientos; generalmente, posee una total falta de información acerca de los mecanismos procesales; ostenta un papel marginal en el desenlace de su causa; la víctima ha de acreditar la veracidad de su relato; debe cumplir con el estereotipo para ser considerada una víctima legítima; etc. De este modo, la dilación en los tiempos y la propia estructura del proceso interfieren decisivamente en la evolución de la integración del acontecimiento traumático". CASTILLEJO MANZANARES, R., TORRADO TARRÍO, C. y ALONSO SALGADO, C., "Mediación en violencia de género", Revista de Mediación, año 4, n 7, mayo 2011, p. 40.

12 SOLETO MUÑOZ, H. "La justicia restaurativa como elemento complementario a la justicia tradicional", en GARCIANDÍA GONZÁLEZ, P.M. y SOLETO MUÑOZ, H. (Dirs.) Sobre la Mediación Penal..., op. cit., p. 47.
} 
Revista Eletrônica de Direito Processual - REDP.

Rio de Janeiro. Ano 11. Volume 18. Número 1. Janeiro a Abril de 2017

Periódico Quadrimestral da Pós-Graduação Stricto Sensu em Direito Processual da UERJ

Patrono: José Carlos Barbosa Moreira. ISSN 1982-7636. pp. 209-235

www.redp.uerj.br

ocasiones, resuelve definitivamente el conflicto $^{13}$.

En cuanto a la recuperación del sentimiento de seguridad, el proceso penal parece olvidar que la mera adopción de medidas de carácter preventivo, en este sentido, no es suficiente y que se precisaría otro tipo de intervención más orientada, precisamente, a la atención de la propia víctima. Las órdenes de alejamiento se incumplen frecuentemente, las pulseras electrónicas de control de los agresores fallan en ocasiones, no se acaba de dar con la tecla exacta que garantice a la víctima su seguridad y tranquilidad, lo que obviamente genera en las mismas una situación de angustia permanente no resuelta, ni mucho menos, por la mera incoación del proceso judicial.

Por último, respecto de la llamada "victimización secundaria", en general, los procesos penales seguidos por delitos de violencia de género suelen suponer una experiencia bastante traumática para la propia víctima que ha de hacer frente no sólo a las consecuencias del delito sufrido, sino además a las derivadas del propio proceso, siendo frecuente en la práctica que las mujeres incluso se nieguen a prestar declaración ante el temor y la desprotección que sienten por parte del sistema de justicia ${ }^{14}$.

Lo fundamental en los supuestos de violencia de género habría de ser, pues, la atención a la víctima y el especial cuidado en la atención de sus intereses y necesidades, sin embargo el proceso judicial, por sí mismo, se muestra incapaz para poder atender debidamente dichos intereses y necesidades. La víctima es quien ha sufrido física, psíquica y materialmente los efectos del delito y, por tanto, ha de hacérsele justicia, pero en la más amplia concepción de la misma y para ello ha de concedérsele un espacio que le ayude a poder reparar el impacto emocional del delito, donde pueda expresarse, poner de manifiesto sus puntos de vista y sus sentimientos, y sienta que éstos son efectivamente tenidos en cuenta. Obviamente, el proceso penal en este momento, tal y como está concebido y pese a los esfuerzos legislativos realizados en este sentido en los últimos tiempos, no ofrece a la víctima dicho marco reparador y de confianza.

La reciente Ley 4/2015, de 27 de abril, del Estatuto de la víctima del delito ${ }^{15}$ incluye diversas

\footnotetext{
${ }^{13}$ A este respecto, ESQUINAS VALVERDE señala que "se entiende que en casos de grave afectación a la dignidad y la integridad moral y psíquica del perjudicado, como son los de violencia de género, la forma de compensar ese daño habrá de manifestar también una intensa dimensión psicológica capaz de contrarrestar, siquiera en grado mínimo, dicho perjuicio igualmente afectivo. Por consiguiente, no parece suficiente la indemnización económica y material, sino que también podría ser recomendable, en principio, como forma de resarcimiento, que el maltratador se sometiera a escuchar el relato de su víctima, recibiera el reproche generalizado de la comunidad asistente a las reuniones, reconociera públicamente su responsabilidad y, eventualmente, accediera a participar en una terapia para superar sus tendencias violentas. Y de esta forma combinada quedaría compensado más adecuadamente el desvalor de acción y de resultado propio de la conducta de maltrato". ESQUINAS VALVERDE, P., Mediación entre víctima y agresor en ..., op. cit., p. 14. ${ }^{14}$ Para JIMÉNEZ MUÑOZ "el silencio de la víctima es, en muchas ocasiones, el muro contra el que se golpea todo el sistema generado para luchar contra la violencia sobre la mujer", JIMÉNEZ MUÑOZ, B., "El silencio de la víctima: guía para no perderse", Revista de Mediación, año 4, n 7, 2011, p. 26.
}

${ }^{15}$ BOE núm. 101, de 28 de abril de 2015. 
Revista Eletrônica de Direito Processual - REDP.

Rio de Janeiro. Ano 11. Volume 18. Número 1. Janeiro a Abril de 2017

Periódico Quadrimestral da Pós-Graduação Stricto Sensu em Direito Processual da UERJ

Patrono: José Carlos Barbosa Moreira. ISSN 1982-7636. pp. 209-235

www.redp.uerj.br

referencias a la posibilidad que tienen las víctimas de acudir a servicios de justicia restaurativa o reparadora. Así, por ejemplo, en el Preámbulo de dicha norma se señala que "la actuación de estos servicios se concibe orientada a la reparación material y moral de la víctima, y tiene como presupuesto el consentimiento libre e informado de la víctima y el previo reconocimiento de los hechos esenciales por parte del autor. En todo caso, la posible actuación de los servicios de justicia restaurativa quedará excluida cuando ello pueda conllevar algún riesgo para la seguridad de la víctima o pueda ser causa de cualquier otro perjuicio"16.

Resulta paradójico que se regule como derecho de la víctima la utilización de servicios de justicia reparadora y restaurativa, cuando ésta no se encuentra regulada legalmente, ni dichos servicios vienen siendo prestados y financiados desde la Administración de Justicia. En cualquier caso, tarde o temprano, la justicia restaurativa encontrará amparo legal en el ámbito del derecho penal de adultos, puesto que ya lo tiene desde hace años en el de los menores infractores, y lo ideal sería que desde la Administración se realicen los esfuerzos que sean necesarios para dotar de medios y recursos a los servicios que lleven a cabo dicha labor para su lograr su debida efectividad.

Por otro lado, con relación al agresor, el actual procedimiento penal genera, además del sufrimiento personal que supone, en su caso, la privación de libertad, la interiorización de actitudes manipuladoras y pautas de desconfianza, un nulo aprendizaje de actitudes empáticas y de respeto a los bienes jurídicos protegidos por el Derecho penal, así como la ausencia de responsabilización

\footnotetext{
${ }^{16}$ Igualmente, en el art. 3 de la citada Ley, cuando se refiere a los derechos de las víctimas se señala en el apartado 1 que "Toda víctima tiene derecho a protección, información, apoyo, asistencia y atención, así como a la participación activa en el proceso penal y a recibir un trato respetuoso, profesional, individualizado y no discriminatorio desde su primer contacto con las autoridades o funcionarios, durante la actuación de los servicios de asistencia y apoyo a las víctimas y de justicia restaurativa...".

En el art. 5, que establece el derecho a la información de la víctima desde el primer contacto con las autoridades competentes, se señala que "toda víctima tiene derecho a recibir, sin retrasos innecesarios, información adaptada a sus circunstancias y condiciones personales y a la naturaleza del delito cometido y de los daños y perjuicios sufridos, sobre los siguientes extremos: (...) k) Servicios de justicia restaurativa disponibles en los casos en que sea legalmente posible". Y, en al art. 15, que lleva por rúbrica Servicios de justicia restaurativa, se establece que "1. Las víctimas podrán acceder a servicios de justicia restaurativa, en los términos que reglamentariamente se determinen, con la finalidad de obtener una adecuada reparación material y moral de los perjuicios derivados del delito, cuando se cumplan los siguientes requisitos: a) el infractor haya reconocido los hechos esenciales de los que deriva sus responsabilidad; b) la víctima haya prestado su consentimiento, después de haber recibido información exhaustiva e imparcial sobre su contenido, sus posibles resultados y los procedimientos existentes para hacer efectivo su cumplimiento; c) el infractor haya prestado su consentimiento; d) el procedimiento de mediación no entrañe un riesgo para la seguridad de la víctima, ni exista el peligro de que su desarrollo pueda causar nuevos perjuicios materiales o morales para la víctima; y e) no esté prohibida por la ley para el delito cometido.

2. Lo debates desarrollados dentro del procedimiento de mediación serán confidenciales y no podrán ser difundidos sin el consentimiento de ambas partes. Los mediadores y otros profesionales que participen en el procedimiento de mediación estarán sujetos a secreto profesional con relación a los hechos y manifestaciones de que hubieren tenido conocimiento en el ejercicio de su función.

3. La víctima y el infractor podrán revocar su consentimiento para participar en el procedimiento de mediación en cualquier momento".
} 
Revista Eletrônica de Direito Processual - REDP.

Rio de Janeiro. Ano 11. Volume 18. Número 1. Janeiro a Abril de 2017

Periódico Quadrimestral da Pós-Graduação Stricto Sensu em Direito Processual da UERJ

Patrono: José Carlos Barbosa Moreira. ISSN 1982-7636. pp. 209-235

www.redp.uerj.br

respecto de la conducta infractora. Estas consecuencias se acompañan además de un intenso deterioro de las facultades físicas y psicológicas, que dificultan los procesos de reinserción social e incrementan las posibilidades de reiteración delictiva ${ }^{17}$.

Según los fines del proceso penal, concebido como instrumento eficaz de política social, éste ha de tender, en primer lugar, a prestar a la víctima la mayor asistencia y reparación posible y, en segundo lugar, a posibilitar la rehabilitación del delincuente y su reintegración social en condiciones que eviten la comisión de nuevos delitos. Sin embargo, nuestro modelo actual de Derecho penal sigue descansando en esa idea de justicia retributiva, donde la víctima es ajena al proceso y sus intereses son representados oficialmente por el Ministerio Fiscal, donde el incremento punitivo y la ampliación de los delitos han sido el modo clásico de intentar satisfacer las demandas sociales de mayor seguridad y donde se consideran como fines de la pena la reinserción y resocialización del infractor, fines que no se cumplen realmente ${ }^{18}$.

Todo ello hace que el proceso judicial se presente como una vía que indudablemente puede ser mejorada o complementada con la adopción de otros recursos que intenten paliar en cierta medidas las deficiencias apuntadas ${ }^{19}$.

La justicia restaurativa tiene como objetivo romper la dicotomía víctima-agresor, intentando variar los papeles predeterminados que se asignan a los mismos en el curso del proceso judicial. En este sentido, se permite al infractor restaurar en la medida de lo posible las consecuencias de sus actos y a las víctimas la posibilidad de participar en dicha reparación. Pero, para ello el infractor ha de tener la voluntad de reparar los daños ocasionados y responsabilizarse por su conducta, porque sólo de esta

\footnotetext{
17 Vid. CASTILLEJO MANZANARES, R., «Mediación en violencia de género, una solución o un problema», en GONZÁlEZ-CUELLAR SERRANO, N. (Dir.) Mediación: un método de ? conflictos, Colex, Madrid, 2010, pp. 197198.

${ }^{18}$ Para URBANO CASTRILLO, “este modelo está moralmente quebrado, no se revela como justo, no previene ni protege, no intimida ni disuade, no rehabilita, no reintegra ni resocializa, no reeduca ni educa, pocas veces atiende las necesidades de delincuentes y víctimas. Todas aquellas utilitarias ambiciones del sistema punitivo han sido prácticamente abandonadas, bajo el atractivo de un propósito de inflingir el daño al ofensor. De este modo resulta que los mecanismos de defensa social se limitan, realmente, a difundir miedo y a intimidar antes que a ocuparse de evitar la reincidencia y de pacificar, verdaderamente, la situación producida por el delito"URBANO CASTRILLO, EDUARDO DE, «La Justicia Restaurativa penal», en La Ley Penal, número 73, Año VII, julio-agosto 2010, p. 7.

${ }^{19}$ A este respecto, destaca LAMARCA PÉREZ que "al menos entre cierto sector de la doctrina, suele ser un lugar común denunciar que el sistema penal, globalmente considerado, resulta no sólo ineficaz, sino dudosamente legítimo. Ineficaz, porque se muestra impotente no ya para eliminar el delito, sino incluso para reducirlo; e ilegítimo por cuanto, para la solución de un conflicto, se limita a imponer un mal, la pena; a todo ello se viene añadiendo que tampoco se ofrece a la víctima satisfacción o una auténtica defensa de sus intereses. Partiendo de estas consideraciones, no puede entonces resultar extraño que también en el ámbito penal haya irrumpido con inusitada fuerza en los últimos años la propuesta de la mediación como alternativa a la solución judicial de los conflictos”. LAMARCA PÉREZ, C., «Una alternativa a la solución judicial de los conflictos: la mediación penal», en La Ley Penal, número 44, Año IV, Diciembre 2007, p. 5.
} 
Revista Eletrônica de Direito Processual - REDP.

Rio de Janeiro. Ano 11. Volume 18. Número 1. Janeiro a Abril de 2017

Periódico Quadrimestral da Pós-Graduação Stricto Sensu em Direito Processual da UERJ

Patrono: José Carlos Barbosa Moreira. ISSN 1982-7636. pp. 209-235

www.redp.uerj.br

forma se conseguirá evitar que la misma se reitere en el futuro ${ }^{20}$.

Entre las ventajas que ofrece la Justicia Restaurativa, se podría destacar que el proceso a seguir va a permitir a todas las partes expresar sus emociones y opiniones sobre las consecuencias de los hechos y sobre la forma en que pueden participar en la posible solución de los mismos. Este potencial para hacer frente a las necesidades psicológicas de los involucrados en episodios de violencia de género, probablemente ayude a disminuir la intensidad de la ansiedad y de los sentimientos negativos que las partes suelen experimentar al enfrentarse a un proceso judicial. De hecho, la Justicia Restaurativa permite a las partes expresar una serie de emociones o de sentimientos que podrían no ser relevantes a efectos legales, pero que a lo mejor sí son muy importantes para las propias partes a fin de dar una solución al conflicto.

Otra de las ventajas que puede ofrecer la Justicia Restaurativa en este ámbito, es que puede proporcionar a la víctima una sensación de control sobre su propio daño, facilitando la reparación en lugar del simple castigo del infractor. La restauración de la sensación de control en la toma de decisiones propias y personales, sin duda, va a facilitar la recuperación del equilibrio emocional de la propia víctima ${ }^{21}$.

Se ofrece un lugar preferente a la víctima, a quien se da un tratamiento especial e individualizado, y los instrumentos de Justicia Restaurativa habrían de configurarse, como ha hecho la Ley que regula el Estatuto de la víctima, como un derecho de ésta, como un recurso al que puede acceder voluntariamente, sin que en ningún caso pueda ser forzada a acudir si éste no es su expreso deseo.

En algunos países, como Estados Unidos, Alemania o Inglaterra, se vienen utilizando instrumentos de Justicia Restaurativa, como la mediación, a fin de que las partes puedan alcanzar acuerdos en lo que concierne a los aspectos civiles derivados de la situación de ruptura provocada por la violencia de género y, además, han comenzado a estudiar la posibilidad de introducir la misma para intentar buscar soluciones más completas a estos casos de violencia de género también por lo que

\footnotetext{
${ }^{20}$ En este sentido, PÉREZ GINÉS señala que "la actual política criminal se muestra contraria al efecto resocializador y preventivo de las penas, y por lo tanto no contribuye a conseguir que el castigado, en muchas ocasiones, entienda la razón de una pena impuesta por unos hechos lejanos y ajenos a su realidad actual”. PÉREZ GINÉS, C.A., «La mediación penal en el ámbito de..., op. cit., p. 66.

Igualmente, ESQUINAS VALVERDE sostiene que "en definitiva, si se dan cuenta de que, razonablemente, podrían haber elegido otra conducta distinta, los agresores sentirán que la Justicia se halla legitimada para sancionarles y estarán más dispuestos a corregir su actitud”. ESQUINAS VALVERDE, P., Mediación entre víctima y agresor en..., op. cit., p. 27.

${ }^{21}$ Para RÍOS MARTÍN, "la mayoría de los hechos delictivos no pueden ser justificados, pero una buena parte de ellos pueden ser comprendidos. Solamente desde la comprensión del comportamiento del otro, la persona víctima puede llegar a calmar su odio y recuperar la serenidad”. RÍOS MARTÍN, J.C., «La mediación, instrumento de diálogo para la reducción de la violencia legal y penitenciaria», en La Ley Penal, número 44, Año IV, Diciembre 2007, p. 25.
} 
Revista Eletrônica de Direito Processual - REDP.

Rio de Janeiro. Ano 11. Volume 18. Número 1. Janeiro a Abril de 2017

Periódico Quadrimestral da Pós-Graduação Stricto Sensu em Direito Processual da UERJ

Patrono: José Carlos Barbosa Moreira. ISSN 1982-7636. pp. 209-235

www.redp.uerj.br

respecta a las cuestiones penales. Se han iniciado programas piloto, cuyo principal fin es que a través de la mediación de un profesional debidamente formado, víctima e infractor consigan comunicarse (no tiene en ningún caso porque ser cara a cara o en persona), a fin de buscar una solución ${ }^{22}$.

En España, hasta la última reforma del Código Penal, en vigor desde el mes de julio de 2015, donde se contempla la mediación en el art. $84.1^{23}$, la única referencia legal expresa a la mediación en el ámbito del Derecho penal de adultos se hacía precisamente para prohibir la misma. Así, en el art. 44.5 de la LO 1/2004, de 28 de diciembre, de Medidas de Protección Integral contra la Violencia de Género, se establece que “En todos estos casos está vedada la mediación”. Se ha optado por prohibir indistintamente la mediación en cualquier supuesto de violencia de género, independientemente de la gran cantidad de posibles supuestos que comprende dicha violencia y de su gravedad, así como de las circunstancias concurrentes en cada caso, lo cual no tiene mucha lógica, ya que como señala CASTILLEJO MANZANARES, “en determinados hechos tipificados como de violencia de género cabría un tratamiento distinto, menos criminalizado, más centrado en el problema como una cuestión de pareja. Y en este marco, la mediación persigue el tratamiento integral del conflicto como instrumento auxiliar de la justicia, con una metodología adaptada a dar una mejor y más apta respuesta a determinados litigios en los que las partes implicadas requieren mantener una relación posterior a la resolución del conflicto en ellas surgido" 24 .

En nuestro país, sin embargo, la mera posibilidad de introducir la Justicia Restaurativa y, en particular, la mediación como instrumento de ésta en este tipo de procesos ha generado numerosas críticas provenientes de diversos sectores que provocaron su expresa prohibición en la Ley Orgánica 1/2004 de Medidas de Protección Integral contra la Violencia de Género, así como la posibilidad de replantear su inclusión con posterioridad a la entrada en vigor de dicha Ley.

Dichas críticas planteaban que la simple posibilidad de hacer un cara a cara entre víctima e infractor podría resultar muy perjudicial para la víctima, imposibilitando cualquier tipo de

\footnotetext{
${ }^{22}$ ESQUINAS VALVERDE señala como fines de estos programas de justicia restaurativa " $11^{\circ}$ detener la acción agresiva; $2^{\circ}$ prestar apoyo y respaldo a las mujeres afectadas y conceder credibilidad a su punto de vista; $3^{\circ}$ conseguir que los agresores se responsabilicen y tomen conciencia del delito cometido y del daño causado; $4^{\circ}$ enviar un mensaje a la comunidad acerca de la seriedad de la infracción y la adopción de respuestas frente a la misma; $5^{\circ}$ y, en menor medida, puesto que resulta más discutido por las personas implicadas y político-criminalmente más controvertido, restaurar las relaciones sociales y familiares deterioradas por el delito". ESQUINAS VALVERDE, P., Mediación entre víctima y agresor en ..., op. cit., p. 24.

${ }^{23}$ El nuevo texto del art. 84.1 del Código Penal establece que el juez o tribunal podrá condicionar la suspensión de la ejecución de la pena al cumplimiento del acuerdo alcanzado por las partes en virtud de mediación.

${ }^{24}$ CASTILLEJO MANZANARES, R., «Mediación en violencia de género, una solución o un problema», en GONZÁLEZ-CUELLAR SERRANO, N. (Dir.) Mediación: un método de..., op. cit. p. 202.
} 
Revista Eletrônica de Direito Processual - REDP.

Rio de Janeiro. Ano 11. Volume 18. Número 1. Janeiro a Abril de 2017

Periódico Quadrimestral da Pós-Graduação Stricto Sensu em Direito Processual da UERJ

Patrono: José Carlos Barbosa Moreira. ISSN 1982-7636. pp. 209-235

www.redp.uerj.br

comunicación y, menos aún, una solución acordada ${ }^{25}$.

Frente a estas críticas, han surgido opiniones diversas, algunas que refrendan y apoyan la postura adoptada por la Ley, otras que la matizan y otras que, directamente, apuestan por la supresión de la prohibición legal.

Así, hay quien opina, siguiendo la posición adoptada por el legislador, que en ningún caso ha de permitirse la mediación en este tipo de asuntos y que, además, dicha prohibición ha de extenderse tanto al ámbito penal como al civil ${ }^{26}$.

Otros autores entienden que sí sería conveniente cuando la violencia es aislada y esporádica, teniendo su origen en situaciones puntuales de crisis familiar ${ }^{27}$.

Otros, por su parte, que sólo sería oportuna para las cuestiones civiles, pero en ningún caso en el ámbito penal.

Otros, que abogan por la supresión de la prohibición y defienden el uso de la mediación incluso en el ámbito penal ${ }^{28}$.

\footnotetext{
${ }^{25}$ Comparto en este sentido las reflexiones de MADRID LIRAS cuando señala que "¿es que si nos cuestionamos que mediar pueda ayudar a éstas nos convertimos en defensores del maltrato?, ¿por qué absurda razón se llega a la idea de que estás a favor de la ley y de las mujeres maltratadas o estás en contra de ambas?, ¿quién decidió que ambas van sumadas?, ¿quién se apoderó del camino único para ayudar a quienes sufren? Colocar a los críticos con esta ley en el bando de los tradicionales que priorizan a la familia frente a la mujer es puro dogmatismo". MADRID LIRAS, S. "Debatir sobre mediación en violencia de pareja", Revista de Mediación, año 4, n 7, mayo 2011, p. 3.

${ }^{26}$ En esta línea, autores como DEL POZO PÉREZ, sostienen argumentos un tanto categóricos y excesivos: “en materia de violencia de género no existe arrepentimiento del autor, simplemente es una estrategia, forma parte de una de las fases del ciclo de la violencia (...). El presunto maltratador de género no se arrepiente por el daño originado a la mujer, sino por las nefastas consecuencias que puede tener para él este comportamiento" (p. 292), "no hay maltrato esporádico" (p. 294), "desigualdad entre las partes en conflicto con la consiguiente falta de equidad, es evidente que este argumento justificaría por sí mismo la prohibición de mediación en violencia de género, sin necesidad de añadir ningún otro" (p. 299), "el poder y la dominación de una parte tenderá a prevalecer en el sustrato de la mediación, con lo cual los posibles acuerdos que se alcanzasen serían producto unilateral, una vez más, de la imposición del más fuerte, del presunto agresor que tiene sometida a la víctima, que la controla, que se impone a la fuerza" (p. 301), "falta de voluntad por consentimiento viciado de la víctima. Inexistencia de voluntariedad. Considero que la víctima de violencia de género podría encontrarse en una situación personal límite que la llevaría a carecer de voluntad, capacidad de decisión e incluso se podría considerar su consentimiento viciado" (p. 303), "la mediación favorece el ciclo de la violencia de género con la contribución a potenciar la luna de miel” (p. 320), "vedar la mediación en este contexto es lo más acertado para tratar de erradicar este preocupante y creciente fenómeno, a un presunto autor que considera inferior a su víctima, que no se arrepiente, que no sabe pedir perdón, que anula su voluntad y que incluso puede aprovecharse de esta alternativa de solución para prolongar el ciclo de la violencia no puede permitírsele, en ningún caso, este método alternativo de canalización del conflicto, la solución única debe ser por tanto el proceso, sin otras alternativas” (p. 324). Vid. DEL POZO PÉREZ, M., ¿Es adecuada la prohibición de mediación del art. 44.5 de la Ley Orgánica 1/2004?, en MARTÍN DIZ, F. (Coord.), La mediación en materia de familia y Derecho penal: estudios y análisis, Andavira Editora, Santiago de Compostela, 2011.

${ }^{27}$ CASANOVAS ET AL "sugieren que se tendría que distinguir entre casos de violencia puntual y de violencia habitual y hacer posible la mediación en episodios de violencia puntual, subrayando la necesidad de asegurar todas las garantías para la víctima y siempre que sirva para mejorar la situación y prevenir futuras situaciones conflictivas, o también para cambiar la situación por una de separación razonable y civilizada". CASANOVAS, P., MAGRE, J. y LAUROBA, M.E., Libro Blanco de la mediación en Cataluña, Generalitat de Catalunya, Departament de Justicia, Barcelona, 2011 , p. 1119. ${ }^{28}$ Por ejemplo, para RÍOS MARTÍN “esta norma prohibitiva debe ser suprimida, pues la limitación que impone no tiene justificación, siempre que la mediación se desarrolle correctamente teniendo en cuenta la asimetría y desigualdad de poder
} 
Revista Eletrônica de Direito Processual - REDP.

Rio de Janeiro. Ano 11. Volume 18. Número 1. Janeiro a Abril de 2017

Periódico Quadrimestral da Pós-Graduação Stricto Sensu em Direito Processual da UERJ

Patrono: José Carlos Barbosa Moreira. ISSN 1982-7636. pp. 209-235

www.redp.uerj.br

Desde mi punto de vista, entiendo que no se puede generalizar, ni frivolizar con un tema tan delicado. Cada episodio de violencia de género es único, no hay dos conflictos idénticos, las partes son distintas y las circunstancias personales y de toda índole que han podido llevar a esa situación también lo son, por tanto habrá que analizar caso por caso para determinar la oportunidad y viabilidad de la Justicia Restaurativa en cada asunto concreto $^{29}$.

No considero conveniente la idea de establecer un catálogo cerrado en el que consten qué asuntos habrían de ser derivados a mediación y cuáles no, y, por supuesto, no todos los asuntos de violencia de género son susceptibles de ser mediados. Es más, posiblemente en muchos de ellos no sea aconsejable ni tan siquiera intentarlo. Habrá que atenderse a las circunstancias concretas del caso en cuestión y, en particular, a la situación emocional de la víctima y la posible desigualdad o desequilibrio en las posiciones de las partes ${ }^{30}$.

No hay que olvidar que la mediación es un proceso de carácter voluntario, por lo que las partes sólo acudirán al mismo cuando se encuentren plenamente convencidas de que dicho proceso puede aportarles algún tipo de beneficio. En ningún caso, se puede forzar a las partes a iniciar un proceso de mediación contra su voluntad, pero en estos supuestos todavía menos por las especiales circunstancias que concurren en ellos. La víctima ha de aceptar iniciar el proceso sólo cuando haya recibido la ayuda psicológica previa que le permita enfrentarse a su agresor en condiciones de absoluta igualdad, si no es así no ha de hacerlo en ningún caso.

Por su parte, los mediadores, como profesionales debidamente especializados, también tienen

que pueden existir en la relación de poder entre víctima y persona acusada”. RÍOS MARTÍN, J.C., La mediación penal y penitenciaria ..., op. cit. p. 107.

${ }^{29}$ Tal y como señala SOLETO MUÑOZ, “cada conflicto tiene sus propias características, las especialidades , el contexto, las razones, las partes, las emociones y el fondo. Por lo tanto, cuando se trata de resolver un conflicto tal vez lo primero que debería estudiarse es serían estos factores, con el fin de decidir cuál es ls mejor forma de resolución". SOLETO MUÑOZ, H. "La justicia restaurativa como elemento complementario a la justicia tradicional", en GARCIANDÍA GONZÁLEZ, P.M. y SOLETO MUÑOZ, H. (Dirs.) Sobre la Mediación Penal..., op. cit., p. 45.

A este respecto, MADRID LIRAS apunta que "meter en un cajón de sastre pocas veces le ha servido a la ciencia para avanzar. Necesitamos el matiz, la diferencia y la excepción para entender la globalidad, casi nunca tan global". MADRID LIRAS, S. "Debatir sobre mediación en violencia...", op. cit., p. 3.

En el mismo sentido, LOBO GUERRA y SAMPER LIZARDI señalan que "no todas las parejas donde ha existido violencia son susceptibles de acudir a la mediación como método de resolución de conflictos. Para poder determiner si su participación es o no viable, es fundamental conocer en profundidad el complejo fenómeno de la violencia en pareja". LOBO GUERRA, M. y SAMPER LIZARDI, F. “¿Es posible la mediación en aquellos casos en los que ha existido violencia de género?", en GARCIANDÍA GONZÁLEZ, P.M. y SOLETO MUÑOZ, H. (Dirs.) Sobre la Mediación Penal..., op. cit., p. 165.

${ }^{30}$ En este sentido, MADRID LIRAS refiere que "en todo caso habrá que dilucidar de qué tipo de violencia en la pareja se trata: si episódica y circunstancial o fruto de una relación de maltrato en busca del debilitamiento sistemático de la pareja y de la muestra de permanente mayor poder sobre el otro. Todas las muestras de violencias son reprochables y deben ser castigadas y frenadas, pero la forma de afrontar un caso u otro, requieren de intervenciones muy ajustadas que ataquen la raíz del problema en cada caso". MADRID LIRAS, S. "Debatir sobre mediación en violencia...”, op. cit., p. 3. 
Revista Eletrônica de Direito Processual - REDP.

Rio de Janeiro. Ano 11. Volume 18. Número 1. Janeiro a Abril de 2017

Periódico Quadrimestral da Pós-Graduação Stricto Sensu em Direito Processual da UERJ

Patrono: José Carlos Barbosa Moreira. ISSN 1982-7636. pp. 209-235

www.redp.uerj.br

la posibilidad de determinar qué supuestos pueden ser mediados y cuáles de ellos no. Si el mediador entiende que existe cualquier tipo de riesgo, por mínimo que sea, para la salud física o emocional de la víctima, en ningún caso ha de permitir que el proceso de mediación siquiera comience ${ }^{31}$.

Privar a la mujer víctima de violencia de género de la posibilidad de utilizar un mecanismo como la mediación que, en determinadas ocasiones, puede reportarle resultados más satisfactorios que los que puede obtener en el proceso judicial coarta evidentemente la autonomía de la mujer y el reconocimiento a su capacidad de adoptar sus propias decisiones libre y voluntariamente en materias que afectan a cuestiones muy personales como pueden ser los desacuerdos que afectan al establecimiento de las relaciones paterno-filiales tras la ruptura o la contribución de cada cónyuge al levantamiento de las cargas económicas ${ }^{32}$.

\section{LA UTILIDAD DE LOS ODR EN LOS CASOS DE VIOLENCIA DE GÉNERO}

Como he apuntado con anterioridad, uno de los mayores recelos que suscita la utilización de instrumentos de justicia restaurativa, como la mediación, en el ámbito de los conflictos de violencia de género es el potencial peligro que puede suponer para la víctima la confrontación con su agresor.

\footnotetext{
${ }^{31}$ Para MUNUERA GÓMEZ y BLANCO LARRIEUX, "se ha de respetar la situación personal de cada mediador frente a la violencia doméstica. Se debe evaluar si este tipo de intervención es apropiado o no según el caso, igual que se realiza en cualquier solicitud de mediación; y si lo es, establecer un protocolo, es decir medidas especiales para comenzar el proceso de mediación, con un diseño especial del centro de mediación (centro con dos puertas, dos salas de espera, etc.)". MUNUERA GÓMEZ, M.P. y BLANCO LARRIEUX, M.E., "Una mirada hacia mediar o no mediar en casos de violencia: Sara Cobb”, Revista de Mediación, año 4, no 7, mayo 2011, p. 37.

${ }^{32}$ LOBO GUERRA y SAMPER LIZARDI señalan que "la prohibición de mediar que la ley establece para los casos de violencia de género incurre en un excesivo paternalismo sobre la mujer, ya que se impide su participación directa en la toma de decisiones sobre cuestiones civiles donde ella es la principal afectada, dando por hecho su incapacidad para participar en el proceso de mediación, sin que tal incapacidad resulte acreditada.

Es cierto que muchas mujeres, tras sufrir una situación de maltrato, y como consecuencia del mismo, pueden presentar un daño psíquico, permanente o transitorio, que les impida participar en el proceso de mediación. Pero, la gravedad de las consecuencias del maltrato depende, entre otros factores, de la severidad del mismo y de la vulnerabilidad de la víctima, evidenciando una amplio abanico de posibles consecuencias en función de cada caso concreto. Además, tras una adecuada intervención psicológica, estas mujeres pueden recuperar la seguridad y establecer el control de sus vidas, abordar las secuelas producidas por la violencia, reforzar su autoestima, recuperar su identidad personal..., pues tales son algunos de los objetivos de estos programas de intervención, y estar dotadas, por tanto, de las habilidades necesarias para hacer frente a un proceso de separación. Pero la prohibición de la ley les priva de este derecho". LOBO GUERRA, M. y SAMPER LIZARDI, F. “¿Es posible la mediación en aquellos casos en los que ha existido violencia de género?”, en GARCIANDÍA GONZÁLEZ, P.M. y SOLETO MUÑOZ, H. (Dirs.) Sobre la Mediación Penal..., op. cit., p. 172.

En el mismo sentido CASTILLEJO MANZANARES ET AL refieren que "la mediación penal favorece el empoderamiento y autonomía de la mujer, proporcionándole herramientas que le faculten para prevenir Estados futuros análogos, al tiempo que hace frente a su situación actual. La mujer deja de ser mostrada como el ser dependiente e incapaz que subyace de la legislación vigente en violencia de género, para convertirse en un ser autonomo capaz de abordar y gestionar su propia realidad". CASTILLEJO MANZANARES, R., TORRADO TARRÍO, C. y ALONSO SALGADO, C., "Mediación en violencia de ...", op. cit., p. 43.

Por su parte, MADRID LIRAS apunta que "solo empoderando a las víctimas conseguiremos que dejen de verse como tales y alcen su voz frente al aggressor para marcar lo que sí están dispuestas y lo que no, lo que sí quieren y lo que no. Y si sentimos o sientan que en el espacio de mediación no se está logrando, siempre tendremos la posibilidad y la obligación de frenarla y de acudir a nuestro legítimo derecho a juicio. No es la mediación solución a todo ni puede con todo. Pero ayuda”. MADRID LIRAS, S. “Debatir sobre mediación en violencia...”, op. cit., p. 4.
} 
Revista Eletrônica de Direito Processual - REDP.

Rio de Janeiro. Ano 11. Volume 18. Número 1. Janeiro a Abril de 2017

Periódico Quadrimestral da Pós-Graduação Stricto Sensu em Direito Processual da UERJ

Patrono: José Carlos Barbosa Moreira. ISSN 1982-7636. pp. 209-235

www.redp.uerj.br

Aunque los encuentros personales suponen probablemente la mayor expresión de las relaciones humanas y suelen ser preferibles cuando utilizamos cualquier mecanismo alternativo de solución de conflictos, hay algunas situaciones en las que dichas reuniones no son convenientes, ni factibles y una de estas situaciones se da cuando pueda existir cualquier tipo de amenaza o violencia del agresor a la víctima, no teniendo por qué ser esta violencia meramente física, sino también verbal o psicológica $^{33}$.

A fin de intentar paliar dichos recelos, la utilización de medios tecnológicos se presenta como una posible vía para introducir elementos de justicia restaurativa en la gestión de los conflictos de violencia de género, toda vez que se evitaría la presencia física de las personas involucradas en el desarrollo del proceso $^{34}$. Si bien se pierden algunos de los elementos que se resaltan como positivos de la justicia restaurativa, como la humanización del proceso, al menos se abre la posibilidad de la comunicación entre víctima e infractor, lo cual es imposible en el marco del proceso judicial.

En los últimos años la utilización de las comunicaciones electrónicas ha sufrido una avance espectacular en todos los ámbitos y sectores de nuestra sociedad, lo que ha supuesto un evidente cambio en la forma de relacionarnos. Como pone de manifiesto SANZ PARRILLA, "estamos sumidos en la denominada Sociedad de la Información, que ha sido definida como una comunidad que utiliza extensivamente y de forma optimizada las oportunidades que ofrecen las tecnologías de la información y las comunicaciones" 35 .

Los ODR abren la posibilidad de realizar encuentros restaurativos a distancia, sin la presencia física de las partes, donde el tercero neutral se va a comunicar con éstas a través de medios tecnológicos. Estos encuentros pueden ser realizados a través de cualquier medio: mensajes de correo electrónico, sesiones de chat, plataformas digitales ad hoc, llamadas telefónicas o videoconferencias en las que se pueden llevar a cabo, por ejemplo, tradicionales sesiones de mediación con las partes

\footnotetext{
${ }^{33}$ Para CAMARERO GONZÁLEZ, "la violencia de carácter psicológico es, quizás, la más sutil y cruel de las violencias. En la mayoría de los casos de maltrato existe una violencia psíquica que puede ejercerse, y de hecho se ejerce de forma previa y que tiene una importancia capital en la génesis y desencadenamiento de situaciones límite. En los malos tratos psicológicos el agresor busca la intimidación, la humillación, la inseguridad personal, la desintegración, la desestructuración, el poder, dominio y control del otro”. CAMARERO GONZÁLEZ, G.J., «Violencia doméstica. Una introducción desde la criminología», en Revista del Ministerio Fiscal, número 13, Ministerio de Justicia, Madrid, 2005. p. 192.

34 Tal y como señala GONZÁLEZ CAMPO, “ el uso de los medios electrónicos no debe contemplarse como la mera utilización de aplicaciones informáticas o medios telemáticos. Antes al contrario, se trata, en realidad, de utilizer la actual tecnología para un mejor servicios". GONZÁLEZ CAMPO, F.A, "Mediación electrónica y proceso: régimen jurídico y oportunidades a la vista de la Ley 18/2011 y Ley 5/2012”, en LAUROBA LACASA, M.E. y ORTUÑO MUÑOZ, P., Mediación es Justicia. El impacto de la Ley 5/2012, de mediación civil y mercantil, Huygens Editorial, Barcelona, 2014, p. 317.

${ }^{35}$ SANZ PARRILLA, M., «El uso de medios electrónicos en la mediación», en SOLETO MUÑOZ, H. (Dir.), Mediación y resolución de conflictos: técnicas y ámbitos, Tecnos, Madrid, 2011, p. 437.
} 
Revista Eletrônica de Direito Processual - REDP.

Rio de Janeiro. Ano 11. Volume 18. Número 1. Janeiro a Abril de 2017

Periódico Quadrimestral da Pós-Graduação Stricto Sensu em Direito Processual da UERJ

Patrono: José Carlos Barbosa Moreira. ISSN 1982-7636. pp. 209-235

www.redp.uerj.br

sin la necesidad de reunir a las mismas en un mismo espacio físico.

Para el buen funcionamiento de un sistema ODR se requiere que el mismo sea accesible, tanto para las partes como para el neutral. El tercero neutral habrá de estar familiarizado con el uso de los recursos electrónicos que vaya a utilizar y habrá de comprobar que las partes, igualmente, no tienen problemas con el manejo de dicha tecnología y que pueden disponer de ella sin ningún tipo de límite o restricción. Además, es importante que los medios utilizados ofrezcan la adecuada garantía de confianza y seguridad.

Los ODR, en principio, fueron concebidos para ser utilizados en procedimientos o disputas de carácter civil o mercantil, y, de hecho, en este campo es dónde gozan de mayor predicación, pero sus ventajas y características pueden ser también perfectamente aplicadas en el ámbito penal y dentro de éste, por qué no, en los asuntos de violencia de género.

Se han realizado experiencias de mediación online en el ámbito familiar, por ejemplo cuando las partes en disputa se encontraban en distintos lugares geográficos o cuando por las especiales circunstancias concurrentes en el caso a mediar, se hacía más recomendable no reunir a las partes en un mismo espacio físico. Sin embargo, no existen experiencias previas o programas que hayan utilizado dicho método para conflictos de violencia de género.

Al igual que sucede con la mediación convencional, la utilización de medios tecnológicos no sirve para todo tipo de asuntos, por tanto hay que velar por que la aplicación de los mismos sea conveniente y adecuada a cada asunto. No tiene sentido aplicar dichos medios indiscriminadamente con carácter general a todo tipo de caso, sino que habrá de realizarse una correcta valoración y selección de los asuntos que habrán de gestionados a través de esta vía, por lo que se presenta como imprescindible la garantía de calidad y experiencia de la institución o personas encargadas de prestar dichos servicios.

Como pone de manifiesto SANZ PARRILLA, "para el correcto funcionamiento de los sistemas de mediación online se necesita un adecuado soporte tecnológico. Si bien es posible realizar una lista de elementos que deben concurrir en estos sistemas, debemos tener en cuenta siempre tres propiedades técnicas: a) Simplicidad: debe tratarse de un proceso fácil de entender y de seguir para las partes; b) Adaptabilidad: debe estar diseñado según las necesidades de las partes; c) Interoperabilidad: debe conectar con el resto de sistemas de los usuarios, partes, mediadores, etc." ${ }^{36}$.

La utilización de mecanismos tecnológicos en los métodos alternativos de solución de conflictos implica una serie de variaciones respecto de su aplicación convencional, fundamentalmente

\footnotetext{
${ }^{36}$ Ibíd., p. 449.
} 
Revista Eletrônica de Direito Processual - REDP.

Rio de Janeiro. Ano 11. Volume 18. Número 1. Janeiro a Abril de 2017

Periódico Quadrimestral da Pós-Graduação Stricto Sensu em Direito Processual da UERJ

Patrono: José Carlos Barbosa Moreira. ISSN 1982-7636. pp. 209-235

www.redp.uerj.br

en lo que se refiere a los aspectos espaciales y temporales, por lo que la comunicación en determinadas ocasiones podrá sincrónica, es decir establecida de manera simultánea entre emisor y receptor, en un mismo tiempo, a través de escritorios compartidos, mensajería instantánea, chats, videoconferencias o telefonía IP, y en otras será asincrónica, realizada en tiempos diferentes, por lo que el receptor no tendrá conocimiento en tiempo real de la comunicación efectuada por el emisor, llevándose cabo a través principalmente de correos electrónicos, aunque existen otras formas como los foros, los mensajes realizados a través de postings o en pizarras electrónicas que se hacen visibles para el tercero neutral y las partes a través de un procedimiento de validación. No hay, en principio mayores impedimentos que los que pueda plantear la conexión a internet. Nada impide tampoco que las partes puedan utilizar el teléfono en un momento determinado para intentar dialogar sobre las cuestiones que estimen oportunas.

Ambos tipos de comunicación, sincrónica y asincrónica tienen sus ventajas y sus inconvenientes, por lo que habrá de determinarse cuál de ellas es más adecuada ${ }^{37}$.

En principio, por su complejidad y por la relación entre las partes, podría parecer más conveniente que, en la mayoría de los casos, la comunicación en los asuntos de violencia de género sea asincrónica, ya que va a permitir a las partes mayor tiempo de reflexión a la hora de elaborar sus mensajes y respuestas, y además al tercero neutral también le va facilitar guiar adecuadamente el proceso, ya que va poder filtrar la información y utilizar las técnicas y reformulaciones oportunas en orden a que los mensajes lleguen de forma indicada a los respectivos receptores.

Sin embargo, en otras ocasiones, cuando las víctimas sientan la necesidad de expresar sus sentimientos o emociones verbalmente a su agresor, la capacidad de avance de la tecnología, específicamente de la videoconferencia, puede hacer factible que se produzcan encuentros

\footnotetext{
${ }^{37}$ A este respecto, señala SUQUET CAPDEVILA que "hoy en día no puede afirmarse que un tipo de comunicación sea más beneficioso que otro, ya que pueden darse elementos contradictorios. Por ejemplo, el email como tecnología asincrónica permite que las partes no contesten apresuradamente y de forma acalorada. Quizás por ello la parte puede reflexionar y contestar en una manera más positiva el mensaje de la otra parte. Ahora bien, en el mismo tipo de comunicación por email una misma parte puede expresar su enfado a través de un mensaje con letras capitales y arruinar una posible solución al conflicto. De hecho, esto es extensible a otras formas de comunicación a través de la red, ya que a pesar de que la información desarrollada a través de un ordenador puede ser vista como impersonal, la cultura de la comunicación online sugiere la existencia de sus propias formas de expresar emociones (como la misma escritura de emails con letras capitales, los emoticonos u otros caracteres especiales).

Los métodos de comunicación sincrónicos, como la videoconferencia o la audioconferencia, presentan una serie de dificultades que hace que todavía no sean mecanismos frecuentemente utilizados en los servicios de ODR. En efecto, además de que es necesario un software determinado para poder establecer esta comunicación, las conferencias de video consumen la mayor parte de la banda ancha. Ello motiva que la comunicación en la mayor parte de las ocasiones no sea tan sencilla y ágil como debería ser y en la práctica la videoconferencia no sea todavía muy usual en la práctica de los proveedores de ODR”. SUQUET CAPDEVILA, J., «Online Dispute Resolution (ODR): una visión jurídica del estado del arte tecnológico», en Revista Vasca de Derecho Procesal y Arbitraje, Tomo XXIII, 2010, pp. 68-69.
} 
Revista Eletrônica de Direito Processual - REDP.

Rio de Janeiro. Ano 11. Volume 18. Número 1. Janeiro a Abril de 2017

Periódico Quadrimestral da Pós-Graduação Stricto Sensu em Direito Processual da UERJ

Patrono: José Carlos Barbosa Moreira. ISSN 1982-7636. pp. 209-235

www.redp.uerj.br

restaurativos de forma muy similar a las mediaciones convencionales donde las partes se encuentran

físicamente con el tercero neutral. De esta forma, se permite que la víctima pueda expresarse perfectamente sin la presión o el miedo que podría sentir de encontrarse en el mismo espacio físico que su agresor.

Si el neutral y las partes lo consideran oportuno, llegado el momento, podría incluso plantearse la posibilidad de utilizar un sistema híbrido que combine sesiones online y reuniones personales, pero, insisto, siempre y cuando el tercero neutral y las partes consideren que es el momento adecuado y que se encuentran debidamente preparados para ello.

La mediación convencional, normalmente, se suele realizar a través de sesiones conjuntas personales del mediador con las partes, a fin de que éstas puedan negociar cara a cara sobre todas aquellas cuestiones que tengan por conveniente. En estas sesiones el mediador despliega todas sus técnicas y hace uso de las herramientas de comunicación necesarias para intentar ayudar a las partes a conseguir un acuerdo. Esto, sin duda, se hace más complicado cuando la mediación se realiza online, ya que el elemento personal o el encuentro físico entre mediador y partes desaparece, por lo que el mediador no podrá hacer uso de determinadas herramientas, habiendo además de adaptar su lenguaje y demás técnicas a las peculiaridades de la comunicación virtual.

La confianza de las partes en el tercero neutral, se configura como un elemento muy importante en la mediación, más aún, si cabe, cuando nos referimos a temas penales, aunque su trasfondo sea de carácter familiar como sucede en los casos de violencia de género. En este sentido, y a fin de no eliminar totalmente el elemento personal podría ser aconsejable que, en aquellos casos en los que fuere posible, el neutral tuviese una primera entrevista con cada una de las partes por separado a fin de presentarse personalmente a las mismas y conseguir al menos de inicio que dicho contacto personal cree el necesario vínculo de confianza que las partes han de tener en el mediador ${ }^{38}$.

Al igual que en la forma de trabajo convencional, es importante que las partes tengan la garantía de la absoluta confidencialidad de las informaciones y comunicaciones que compartan durante el proceso online, porque va a ser la única forma de facilitar que éstas consigan abrirse y sincerarse con

\footnotetext{
${ }^{38}$ En el mismo sentido, FEMENIA sostiene que "sin un buen rapport entre el mediador y las partes, es muy difícil hacer el proceso de mediación. Esto es una dificultad al planear usar sólo ODR para hacer la mediación familiar. En las reuniones presenciales, hay un montón de información sensorial que ayuda a establecer confianza en el proceso. Aún, una conferencia telefónica puede aportar más de esta confianza, por eso se dice que idealmente hay que comenzar con una reunión cara a cara para clarificar el proceso, establecer la confianza y verificar las condiciones para un diálogo efectivo entre los tres lados, para luego continuar online. La llamada telefónica tiene que estar disponible a lo largo del proceso para agregar más de esta textura de confianza en la interacción, especialmente si aparecen obstáculos al progreso de la mediación”. Vid. FEMENIA, N., «Mediación familiar online: ¿ayuda o desafío?», disponible en: http://www.norafemenia.com/im/mediaciondivorcioonline_files/frame.htm
} 
Revista Eletrônica de Direito Processual - REDP.

Rio de Janeiro. Ano 11. Volume 18. Número 1. Janeiro a Abril de 2017

Periódico Quadrimestral da Pós-Graduação Stricto Sensu em Direito Processual da UERJ

Patrono: José Carlos Barbosa Moreira. ISSN 1982-7636. pp. 209-235

www.redp.uerj.br

el neutral, sin ocultar ningún tipo de información que pueda resultar relevante para la resolución del conflicto. Por tanto, el tercero neutral o la institución encargada de prestar el servicio habrán de garantizar tanto la confidencialidad, como la seguridad de las informaciones y mensajes transmitidos online, debiendo asegurarse además de que los mensajes han sido transmitidos y recibidos correctamente por emisor y destinatario. Esto incluye también los posibles archivos agregados, faxes, chats, así como cualquier otro tipo de archivo o medio de la red utilizado como parte de la comunicación electrónica.

Uno de los problemas o de los mayores peligros que presentan los ODR es la eventual violabilidad de las comunicaciones, si bien, en este sentido, se ha avanzado bastante y, hoy por hoy, es muy alto el número de operaciones y transacciones electrónicas que se realizan cada día de forma segura, habiéndose creado al efecto mecanismos, como la firma electrónica, que actúan eficientemente y que pueden dotar de dicha garantía de seguridad a las comunicaciones realizadas durante su utilización.

\subsection{Ventajas que pueden ofrecer los ODR en el ámbito de la Justicia Restaurativa y, en} concreto, en los casos de violencia de género

Como he venido argumentando, la Justicia Restaurativa se presenta como una alternativa más acorde para dar soluciones a determinados conflictos que el proceso penal clásico y, en este sentido, la utilización de medios técnicos puede configurarse como un foro más accesible y seguro para dar cabida a la utilización de instrumentos de justicia restaurativa, como la mediación, en los conflictos de violencia de género.

La utilización de los recursos tecnológicos aplicables a la justicia restaurativa puede ampliar las opciones de reparación para las víctimas de violencia de género, además de proporcionar a todos los implicados las ventajas inherentes a los fines y principios de dicha justicia restaurativa, teniendo la posibilidad de expresarse a fin de intentar alcanzar un acuerdo conforme a los intereses y necesidades de los mismos.

Las víctimas quieren un entorno seguro para poder expresarse libremente, pero también desean

precisamente eso, es decir, poder expresarse y tener la oportunidad de poder contar al agresor su versión de los hechos y, en este sentido, los ODR les ofrecen al menos dicha oportunidad. Las mujeres agredidas no se van a ver obligadas a ocultar sus emociones, como si estuviesen físicamente en una reunión con el tercero neutral y el agresor. En muchas ocasiones, el hecho de encontrarse físicamente con otras personas en una misma sala o espacio físico va a provocar la necesidad de reprimir la ira en sus expresiones o en el tono de las palabras, a fin de guardar las formas, sin embargo a través de la 
Revista Eletrônica de Direito Processual - REDP.

Rio de Janeiro. Ano 11. Volume 18. Número 1. Janeiro a Abril de 2017

Periódico Quadrimestral da Pós-Graduação Stricto Sensu em Direito Processual da UERJ

Patrono: José Carlos Barbosa Moreira. ISSN 1982-7636. pp. 209-235

www.redp.uerj.br

utilización de instrumentos tecnológicos las víctimas van a ser libres para expresar dicha ira sin la presencia de otras partes. Sin la presión añadida de tener que ser colaborativas en aras de buscar una solución satisfactoria para todas las partes implicadas, las víctimas en su intimidad pueden verse más fortalecidas para hacer valer con mayor decisión sus propios intereses, haciendo frente a sus agresores, sin tener que preocuparse de perder las formas en un momento determinado.

Por su parte, los agresores en ocasiones también pueden sentir la necesidad de expresar una serie de sentimientos o de emociones, como el arrepentimiento, que encontrándose presente en una reunión con otras personas a lo mejor esconden, pero que sin embargo podrían expresar más libremente a través de la utilización de los ODR.

Otra de las ventajas de los ODR es que son mucho más rápidos, toda vez que la comunicación es inmediata por lo que se agilizan todas las actuaciones que haya que realizar. Se reducen además los costes económicos ya que se evitan los desplazamientos de las partes o del neutral, pudiendo realizarse las comunicaciones incluso desde el propio domicilio.

Por otra parte, los ODR potencian aún más la flexibilidad del proceso elegido, ya que se pueden realizar las comunicaciones en cualquier tiempo, no hay sujeción a horarios predeterminados, por lo que se puede diseñar un procedimiento en el que las partes pueden organizar su tiempo como deseen, según sus conveniencias y su necesidad de reflexión ${ }^{39}$.

Es fundamental que en el proceso las partes puedan comunicarse en absoluta igualdad de condiciones y que sus posiciones estén debidamente equilibradas. En este sentido, uno de los objetivos precisamente de la mediación es equilibrar las posiciones de las partes en el proceso a fin de que no exista ninguna desigualdad de fuerzas. Pero puede haber situaciones en las que el mediador no se de cuenta que el agresor está tratando de coaccionar o intimidar a la víctima, porque por ejemplo esté utilizando gestos, palabras o expresiones que sólo la víctima conoce y que ésta puede percibir como amenazantes. En este caso también, la separación física de las partes puede eliminar o anular la capacidad del agresor de poder manipular con sus movimientos o actitudes la libertad e independencia de la víctima.

Por otro lado, probablemente, la ausencia de los abogados en las sesiones convencionales puede provocar que se reduzca la capacidad de la víctima de defender adecuadamente sus propios derechos e intereses, máxime cuando existe una situación de temor de la víctima hacia su agresor que puede provocar que ésta pueda renunciar a derechos que, de haber estado presente su letrado, no habría

\footnotetext{
${ }^{39}$ Vid. SANZ PARRILLA, M., «El uso de medios electrónicos en la mediación», en SOLETO MUÑOZ, H. (Dir.), Mediación y resolución de..., op. cit., pp.. 441-442.
} 
Revista Eletrônica de Direito Processual - REDP.

Rio de Janeiro. Ano 11. Volume 18. Número 1. Janeiro a Abril de 2017

Periódico Quadrimestral da Pós-Graduação Stricto Sensu em Direito Processual da UERJ

Patrono: José Carlos Barbosa Moreira. ISSN 1982-7636. pp. 209-235

www.redp.uerj.br

llevado a cabo. En este sentido, también, los ODR pueden contribuir a paliar dicho riesgo, toda vez que las partes no han de adoptar decisiones precipitadas que pueden ser fruto de la situación de tensión del momento, sino que van a disponer un mayor período de reflexión en el que van a poder hacer las consultas pertinentes a sus abogados a fin de determinar que es lo más conveniente.

En cierta medida también puede salvaguardar la propia neutralidad del tercero que al no tener presentes a las partes, puede eliminar cualquier tipo de estereotipo o posible prejuicio que el mismo pudiese tener sobre por ejemplo la presencia física o aspecto que las partes puedan tener. Igualmente, el tono de la voz o el lenguaje no verbal o corporal de éstas no podrá ser malinterpretado por el neutral al no tener contacto personal directo con las mismas.

Precisamente, una de las limitaciones que se han venido señalando de la utilización de los ODR es la imposibilidad de las partes y del tercero neutral de observar la comunicación no verbal. Si bien es cierto que el lenguaje corporal o la comunicación no verbal supone un factor muy importante en las reuniones convencionales, toda vez que puede proporcionar gran cantidad de información acerca del estado de ánimo de las partes o de sus emociones a lo largo del desarrollo de las sesiones, su ausencia en los ODR también puede tener sus connotaciones positivas, toda vez que, dada la especial naturaleza de los conflictos de violencia de género, el hecho de no reunir en un mismo espacio físico a víctima y agresor va a facilitar que éstos se sientan más cómodos, menos coartados a la hora de poder expresar libremente sus sentimientos y emociones, por lo que dicho lenguaje corporal ya no va a ser tan relevante o no va a proporcionar demasiada información al neutral.

Además, los espacios de tiempo que transcurren en la transmisión de mensajes online entre el tercero neutral y las partes pueden facilitar la reflexión, el análisis de los mismos e incluso la retractación de alguno de ellos. Las partes van a tener la oportunidad de pensar más pausadamente sus diferencias y de responder a los mensajes de la otra parte o del neutral una vez pensada y buscada la respuesta adecuada.

Por último, otra de las ventajas que ofrecen los ODR es la posibilidad de contar con el tercero neutral que elijan las partes, incluso aunque éste no se encuentre en el mismo espacio geográfico que ellas, pudiendo incluso encontrarse en países diferentes, sin que por ello el coste del proceso tenga por qué ser necesariamente mayor.

\subsection{El papel del neutral en los ODR}

El papel que ha desarrollar el tercero neutral en los ODR es fundamental porque ha de combinar las técnicas y estrategias propias del método elegido con los instrumentos tecnológicos adecuados a cada situación. El neutral debe propiciar el marco adecuado para conseguir gestionar los sentimientos 
Revista Eletrônica de Direito Processual - REDP.

Rio de Janeiro. Ano 11. Volume 18. Número 1. Janeiro a Abril de 2017

Periódico Quadrimestral da Pós-Graduação Stricto Sensu em Direito Processual da UERJ

Patrono: José Carlos Barbosa Moreira. ISSN 1982-7636. pp. 209-235

www.redp.uerj.br

contrarios de las partes y presentar adecuadamente las ventajas que puede suponer para las mismas el proceso y ello ha de hacerlo sin tener presentes a las mismas.

La figura del neutral online también es crucial en orden a detectar posibles movimientos del agresor encaminados a intentar manipular o coaccionar de cualquier modo a la víctima a través de los mensajes o de la utilización del lenguaje que esté realizando a través de la red, por lo que deberán recibir formación adecuada con el fin de conocer y poder manejar este lenguaje virtual y evitar que pueda producirse vulneración alguna de la situación de equilibrio entre las partes.

En este sentido, los ODR facilitan al neutral su intervención en orden a prevenir los posibles intentos del agresor de manipular a la víctima, toda vez que va a poder restringir los canales de comunicación entre ambos si lo considera necesario, haciendo que determinados mensajes del agresor no lleguen a la víctima, o bien lleguen debidamente filtrados por el mismo a fin de que no puedan tener efectos nocivos sobre ésta o sobre el propio proceso.

El neutral puede trabajar reflexivamente en la reformulación de los mensajes a fin de que lleguen de forma adecuada y puedan ser correctamente entendidos por sus destinatarios. También va a tener más tiempo de reacción a la hora de seleccionar su estrategia o las técnicas a utilizar en función de cómo vayan desarrollándose las comunicaciones entre las partes. Puede trabajar con las partes el lenguaje a utilizar, intentar adecuarlo al buen fin del proceso, también puede permitir a éstas la posibilidad de discutir acerca de cualquier tema y hablar con más libertad en un determinado momento.

Es importante que el neutral compruebe que las partes están debidamente familiarizadas con todos los recursos tecnológicos que vayan a ser empleados durante el proceso y si hay alguna de ellas que desconoce o no controla adecuadamente alguno de estos recursos, habrá de recibir la formación adecuada al respecto, a fin de que no exista la más mínima desigualdad en tal sentido.

Hoy en día, los imparables avances tecnológicos abren un campo ilimitado de posibilidades a los neutrales que quieran formarse en este ámbito.

El tercero neutral ha de tener formación específica en violencia de género ${ }^{40}$ y ha de encontrarse

\footnotetext{
40 Para CÁRDENAS, "lo primero que debe saber el mediador o mediadora es que hay que distinguir entre casos de violencia y casos con violencia (...) Es bueno que el mediador o la mediadora, sea un hombre o una mujer con experiencia en familia y específicamente en violencia. Si no la tiene, necesita ayuda de alguien experimentado. Ésta es la primera condición para encarar una mediación en estos casos". CÁRDENAS, E.J., La mediación en conflictos familiares, Lumen, Buenos Aires, 1999, pp. 212-213.

Igualmente, CASTILLEJO MANZANARES ET AL señalan "la absoluta necesidad de que las y los mediadores se especialicen en este campo y estén sometidos permanentemente a un continuo reciclaje de conocimientos, prácticas, etc.". CASTILLEJO MANZANARES, R., TORRADO TARRÍO, C. y ALONSO SALGADO, C., "Mediación en violencia de ..., op. cit., p. 44.
} 
Revista Eletrônica de Direito Processual - REDP.

Rio de Janeiro. Ano 11. Volume 18. Número 1. Janeiro a Abril de 2017

Periódico Quadrimestral da Pós-Graduação Stricto Sensu em Direito Processual da UERJ

Patrono: José Carlos Barbosa Moreira. ISSN 1982-7636. pp. 209-235

www.redp.uerj.br

perfectamente familiarizado con los recursos tecnológicos que vaya a emplear, pues en todo caso habrá de adaptar a ellos las técnicas y herramientas que vaya a utilizar durante el proceso.

Por tanto, deberá estar habituado al lenguaje electrónico, habiendo de estar al tanto de las normas de protocolo y cortesía utilizadas en este tipo de comunicación. Así, es importante extremar el cuidado en el lenguaje escrito, habiendo de cuidar la ortografía, evitar reenvíos y contestaciones en un mismo mensaje a fin de que no se puedan filtrar informaciones o comentarios que no deberían haber llegado a una de las partes, ha de evitar también el uso de mayúsculas fuera de los casos establecidos gramaticalmente, ya que el uso de las mismas en el lenguaje electrónico viene asociado a mensajes agresivos, por lo que podrían causar una sensación incómoda en el receptor; la tipografía y los colores utilizados deben ser adecuados, intentando transmitir mediante el lenguaje escrito la misma sensación de tranquilidad que ha de generar el neutral en una sesión convencional.

Además, el neutral ha de ser capaz de diseñar el procedimiento electrónico a seguir, teniendo en cuenta las necesidades de las partes, habiendo de asegurarse de que las mismas tengan las mismas oportunidades durante su desarrollo, garantizando, en definitiva, la plena igualdad entre éstas ${ }^{41}$.

En cuanto a la imparcialidad del neutral, al celebrarse las sesiones a distancia va a resultar más complicado que las partes lleguen a percibirla adecuadamente, por lo que éste habrá de cuidarse de que ambas se sientan igualmente atendidas en todo momento. Así, habrá de contestar con la misma rapidez a las comunicaciones de las dos partes, habrá de mantenerlas informadas continuamente del desarrollo del proceso y remitirles igualmente resúmenes de toda la actividad desplegada, haciéndoles sentir que dicho esquema de comunicación garantiza que sus intereses están debidamente salvaguardados.

En principio, todas las fases del proceso elegido podrían ser desarrolladas de forma electrónica, desde la sesión informativa a la firma del acuerdo. El neutral habrá de indicar a las partes qué medios electrónicos van a ser utilizados a lo largo del proceso, éstos podrán ser simplemente correos electrónicos, pero como ya he comentado también se podrán utilizar otros, como la videoconferencia, que pueden aportar un plus en un momento determinado. También habrá de asegurarse de que las partes conocen perfectamente el uso de dichos medios, a fin de garantizar que no se puedan producir eventuales desigualdades por tal circunstancia.

\section{CONCLUSIONES}

Que la violencia de género es un fenómeno preocupante es un hecho evidente y también lo es

\footnotetext{
${ }^{41}$ Vid. SANZ PARRILLA, M., «El uso de medios electrónicos en la mediación», en SOLETO MUÑOZ, H. (Dir.), Mediación y resolución de..., op. cit., pp. 447-448.
} 
Revista Eletrônica de Direito Processual - REDP.

Rio de Janeiro. Ano 11. Volume 18. Número 1. Janeiro a Abril de 2017

Periódico Quadrimestral da Pós-Graduação Stricto Sensu em Direito Processual da UERJ

Patrono: José Carlos Barbosa Moreira. ISSN 1982-7636. pp. 209-235

www.redp.uerj.br

que las reformas legales realizadas hasta la fecha no han surtido los efectos esperados, por lo que se hace necesario implementar nuevos recursos que vengan a intentar mejorar, en la medida de lo posible, la situación actual.

En el ámbito de la violencia de género, se ha de ofrecer a las víctimas la posibilidad de optar por mecanismos, no ya alternativos al proceso judicial, sino complementarios a éste, que les permitan, como ejercicio de su propia capacidad de autodeterminación, satisfacer intereses y necesidades que en el procedimiento judicial no pueden conseguir. Ahora bien, para ello ha de tenerse en cuenta principalmente la voluntariedad, así como la idoneidad de tal opción, habiendo de ser valorada ésta última por profesionales debidamente cualificados y especializados en la materia.

Una de las mayores ventajas que pueden ofrecer los ODR es que a través de ellos los programas de Justicia Restaurativa podrían ser accesibles para las víctimas de violencia de género que voluntariamente quisieran acudir a los mismos, suprimiendo el principal temor que suscita su utilización, cual es la confrontación directa de la víctima con su agresor y las posibles consecuencias negativas que podrían derivarse para ésta. La eliminación física y real del peligro que podría suponer el encuentro entre agresor y víctima quedaría salvaguardada mediante el uso de los ODR e implicaría poder introducir elementos de justicia restaurativa donde hasta la fecha sólo existen elementos de justicia retributiva.

Uno de los problemas que nos podemos encontrar en la actualidad, más que la utilización de los ODR en sí, es que existen pocos programas y pocos servicios de justicia restaurativa y que tanto las víctimas, como el resto de personas y operadores jurídicos implicados en los procesos de violencia de género desconocen la existencia de los mismos, por lo que se hace necesario trabajar activamente en este sentido.

Obviamente, si además de promocionar la justicia restaurativa, se facilita su implementación con la dotación de recursos que permitan su utilización con medios tecnológicos, será mucho más fácil su difusión y el acceso a la misma para un mayor número de personas que podrán hacer uso de ella aunque en la localidad donde residan no dispongan de programas de justicia restaurativa, ya sea con carácter institucionalizado o experimental. No todo el mundo tiene acceso a Internet en sus hogares, pero sí cada vez más personas pueden disponer de él de alguna forma, bien sea a través de instituciones públicas, como bibliotecas, centros sociales u otros servicios municipales, o privadas, por lo que los ODR se presentan como un recurso accesible y seguro que podría permitir abrir el camino para la introducción de métodos complementarios de gestión de conflictos y de elementos de justicia restaurativa en los asuntos de violencia de género. 
Revista Eletrônica de Direito Processual - REDP.

Rio de Janeiro. Ano 11. Volume 18. Número 1. Janeiro a Abril de 2017

Periódico Quadrimestral da Pós-Graduação Stricto Sensu em Direito Processual da UERJ

Patrono: José Carlos Barbosa Moreira. ISSN 1982-7636. pp. 209-235

www.redp.uerj.br

\section{BIBLIOGRAFÍA}

CAMARERO GONZÁLEZ, G.J., «Violencia doméstica. Una introducción desde la criminología», en Revista del Ministerio Fiscal, número 13, Ministerio de Justicia, Madrid, 2005.

CÁRDENAS, E.J., La mediación en conflictos familiares, Lumen, Buenos Aires, 1999.

CASANOVAS, P., MAGRE, J. y LAUROBA, M.E., Libro Blanco de la mediación en Cataluña, Generalitat de Catalunya, Departament de Justicia, Barcelona, 2011

CASTILLEJO MANZANARES, R., «Mediación en violencia de género, una solución o un problema», en GONZÁLEZ-CUELLAR SERRANO, N. (Dir.) Mediación: un método de ? conflictos, Colex, Madrid, 2010.

CASTILlEJO MANZANARES, R., TORRADO TARRÍO, C. y ALONSO SALGADO, C., “Mediación en violencia de género”, Revista de Mediación, año 4, nº 7, mayo 2011.

DEL POZO PÉREZ, M., «¿Es adecuada la prohibición de mediación del art. 44.5 de la Ley Orgánica 1/2004?», en MARTÍN DIZ, F. (Coord.), La mediación en materia de familia y Derecho penal: estudios y análisis, Andavira Editora, Santiago de Compostela, 2011.

ESQUINAS VALVERDE, P., Mediación entre víctima y agresor en la violencia de género, Tirant lo Blanch, Valencia, 2008.

FEMENIA, N., «Mediación familiar online: ¿ayuda o desafío?», disponible en:

http://www.norafemenia.com/im/mediaciondivorcioonline_files/frame.htm

GONZÁLEZ CAMPO, F.A, “Mediación electrónica y proceso: régimen jurídico y oportunidades a la vista de la Ley 18/2011 y Ley 5/2012”, en LAUROBA LACASA, M.E. y ORTUÑO MUÑOZ, P., Mediación es Justicia. El impacto de la Ley 5/2012, de mediación civil y mercantil, Huygens Editorial, Barcelona, 2014.

JIMÉNEZ MUÑOZ, B., “El silencio de la víctima: guía para no perderse”, Revista de Mediación, año 4, no 7, 2011.

LAMARCA PÉREZ, C., «Una alternativa a la solución judicial de los conflictos: la mediación penal», en La Ley Penal, número 44, Año IV, Diciembre 2007.

LOBO GUERRA, M. y SAMPER LIZARDI, F. “¿Es posible la mediación en aquellos casos en los que ha existido violencia de género?”, en GARCIANDÍA GONZÁLEZ, P.M. y SOLETO MUÑOZ, H. (Dirs.) Sobre la Mediación Penal (Posibilidades y Límites en un Entorno de Reforma del Proceso Penal Español), Thomson Reuters Aranzadi, Navarra, 2012. 
Revista Eletrônica de Direito Processual - REDP.

Rio de Janeiro. Ano 11. Volume 18. Número 1. Janeiro a Abril de 2017

Periódico Quadrimestral da Pós-Graduação Stricto Sensu em Direito Processual da UERJ

Patrono: José Carlos Barbosa Moreira. ISSN 1982-7636. pp. 209-235

www.redp.uerj.br

MADRID LIRAS, S. "Debatir sobre mediación en violencia de pareja”, Revista de Mediación, año $4, \mathrm{n}^{\circ} 7$, mayo 2011

MUNUERA GÓMEZ, M.P. y BLANCO LARRIEUX, M.E., "Una mirada hacia mediar o no mediar en casos de violencia: Sara Cobb”, Revista de Mediación, año 4, n 7, mayo 2011.

OUBIÑA BARBOLLA, S., «La distancia que les separa, la distancia que nos separa: mediación en casos de violencia doméstica en España y en otros sistemas», en GARCIANDÍA GONZÁLEZ, P.M. y SOlETO MUÑOZ, H. (Dirs.) Sobre la Mediación Penal (Posibilidades y Límites en un Entorno de Reforma del Proceso Penal Español), Thomson Reuters Aranzadi, Navarra, 2012.

PÉREZ GINÉS, C.A., «La mediación penal en el ámbito de la violencia de género (o las órdenes de protección de difícil control y cumplimiento)», en La Ley Penal, número 71, año VII, mayo 2010.

PERULERO GARCÍA, D., "Hacia un modelo de justicia restaurativa: la mediación penal”, en GARCIANDÍA GONZÁLEZ, P.M. y SOLETO MUÑOZ, H. (Dirs.), Sobre la Mediación Penal (Posibilidades y Límites en un Entorno de Reforma del Proceso Penal Español), Thomson Reuters Aranzadi, Navarra, 2012.

RÍOS MARTÍN, J.C., «La mediación, instrumento de diálogo para la reducción de la violencia legal y penitenciari»a, en La Ley Penal, número 44, Año IV, Diciembre 2007.

RIOS MARTíN, J., PASCUAL RODRÍGUEZ, E., BIBIANO GUILLÉN, A., SEGOVIA BERNABÉ, J.L., La mediación penal y penitenciaria. Experiencias de diálogo en el sistema penal para la reducción de la violencia y el sufrimiento humano, Colex, Madrid, 2008.

SANZ PARRILLA, M., «El uso de medios electrónicos en la mediación», en SOLETO MUÑOZ, H. (Dir.), Mediación y resolución de conflictos: técnicas y ámbitos, Tecnos, Madrid, 2011.

SOLETO MUÑOZ, H., «La Mediación en la Unión Europea», en Mediación y solución de conflictos. Habilidades para una necesidad emergente, en SOLETO MUÑOZ, H. y OTERO PARGA, M. (Coord.), Tecnos, Madrid, 2007.

SOLETO MUÑOZ, H. "La justicia restaurativa como elemento complementario a la justicia tradicional”, en GARCIANDÍA GONZÁLEZ, P.M. y SOLETO MUÑOZ, H. (Dirs.), Sobre la Mediación Penal (Posibilidades y Límites en un Entorno de Reforma del Proceso Penal Español), Thomson Reuters Aranzadi, Navarra, 2012.

SUQUET CAPDEVILA, J., «Online Dispute Resolution (ODR): una visión jurídica del estado del arte tecnológico», en Revista Vasca de Derecho Procesal y Arbitraje, Tomo XXIII, 2010.

URBANO CASTRILLO, EDUARDO DE, «La Justicia Restaurativa penal», en La Ley Penal, número 73, Año VII, julio-agosto 2010. 
Revista Eletrônica de Direito Processual - REDP.

Rio de Janeiro. Ano 11. Volume 18. Número 1. Janeiro a Abril de 2017

Periódico Quadrimestral da Pós-Graduação Stricto Sensu em Direito Processual da UERJ

Patrono: José Carlos Barbosa Moreira. ISSN 1982-7636. pp. 209-235

www.redp.uerj.br

VALL RIUS, A. y GUILLAMAT RUBIO, A., "Mediación y violencia de género, una respuesta útil

en los casos de archivo de la causa penal”, Revista de Mediación, año 4, nº 7, mayo 2011

ZAFRA ESPINOSA DE LOS MONTEROS, R., "La mediación penal: una alternativa a la resocialización", en GARCIANDÍA GONZÁLEZ, P.M. y SOLETO MUÑOZ, H. (Dirs.) Sobre la Mediación Penal (Posibilidades y Límites en un Entorno de Reforma del Proceso Penal Español), Thomson Reuters Aranzadi, Navarra, 2012. 